\title{
The Inhibitory Effect of Baicalin on the Short-Term Food Intake in C57BL/6J Mice
}

\author{
Eun-Ho KIM ${ }^{1}$, Rak-Ho Son ${ }^{1}$, Hyeon-Jong MYounG ${ }^{1}$, Woongchon MAR ${ }^{2}$, Won-Ki KIm ${ }^{3}$, and Kung-Woo NAM ${ }^{1,2,3, *}$ \\ ${ }^{1}$ Jung San Bio Technology, Hwaseong 445-964, ${ }^{2}$ Natural Products Research Institute, College of pharmacy, \\ Seoul National University, Seoul 151-742, ${ }^{3}$ Department of Neuroscience, College of Medicine, \\ Korea University, Seoul 136-701, Republic of Korea
}

(Received February 18, 2010; Revised March 19, 2010; Accepted March 22, 2010)

\begin{abstract}
Appetite is inhibited by the anorexigenic neuropeptides POMC (proopiomelanocortin) and CART (cocaine-amphetamine-regulated transcript) in the hypothalamus. The present study was performed to examine the inhibitory effects of baicalin against food intake and the upregulation of POMC/CART. Short-term food intake $(48 \mathrm{~h})$ was significantly inhibited by treatment with baicalin $(10 \mathrm{mg} / \mathrm{kg}, p<0.05)$ in C57BL/6 mice. Immunohistochemical analysis showed that baicalin upregulated POMC and CART levels in the arcuate nucleus of the hypothalamus. These effects were also examined using an in vitro system. pPOMC-Luc or pCART-Luc plasmids were transformed into mouse N29-2 neuronal and human SH-SY5Y cells, and the activities of baicalin were examined in these cells. Baicalin increased POMC and CART promoter-driven luciferase activity in a dose-dependent manner without cytotoxic effects. These results suggest that baicalin downregulates short-term food intake while upregulating POMC and CART expression.
\end{abstract}

Keywords: Baicalin, Scutellaria baicalensis, POMC, CART, Food intake

\section{INTRODUCTION}

Feeding is regulated strictly by appetite-related neuropeptides, which are expressed in the feeding center in the hypothalamus (Schwartz et al., 2000; Morton et al., 2006; Murphy and Bloom, 2006). The main factors involved in control of feeding are the opposing controls between the orexigenic neuropeptide $\mathrm{Y}$ (NPY)/agouti-related protein (AgRP) neurons and the anorexigenic proopiomelanocortin (POMC)/cocaine-amphetamine-regulated transcript (CART) neurons, which originate from the arcuate nucleus to the paraventricular nucleus (Kalra and Kalra, 2003; O'Rahilly and Yeo, 2004; Higuchi et al., 2006; Murphy and Bloom, 2006).

Among the anorexigenic neuropeptides, melanocortin is a series of peptides that are cleaved to POMC, the ligand of melanocortin receptors (Eberle, 2000). Melanocortin receptors (MCRs) belong to a superfamily of seven-transmembrane $G$ protein-coupled receptors, consisting of five subtypes, MC1R-MC5R (Gantz and Fong, 2003; Chai et

${ }^{*}$ Corresponding author

Tel: +82-31-373-1021 Fax: +82-31-375-1023

E-mail: kwnam1@snu.ac.kr al., 2007). MC3 (MC3R) and MC4 (MC4R) expressed in the brain play important roles in maintaining body weight (Fan et al., 1997; Ollmann et al., 1997; Catania, 2008; Fu and van den Pol, 2008). MC4R is an established regulator of food intake and body weight, and blockade of this receptor causes obesity (Cone, 2000; O'Rahilly et al., 2004). These results indicate that MC4R signals play an important role in the regulation of food intake and obesity.

In contrast, excess ligand binding to these receptors can reduce obesity through reduced food consumption (Irani and Haskell-Luevano, 2005; Emmerson et al., 2007). Thus, modulators that promote POMC and CART expression are potential new lead compounds for controlling obesity (Vicentic and Jones, 2007; Coll and Loraine-Tung, 2009). Despite their potential, however, compounds that upregulate the expression of POMC and CART have not been explored in detail. To search for new lead compounds that up-regulate the expression of POMC and CART, more than 2,300 plant extracts were tested for their transcription promoting activity.

Baicalin is known to have multiple biological functions, including antibacterial (Huang et al., 2009), anti-inflammatory (Lin et al., 2008), antiviral (Li et al., 2000; Wang et al., 
2004), and antitumor effects (Chan et al., 2000; Wang et al., 2008; Li-Weber, 2009). However, the relationships between food intake and the anorexigenic neuropeptides have not been reported.

In this study, we isolated baicalin from the root of Scutellaria baicalensis Georgi (Labiatae) using activity guided purification and examined its effects on anorexigenic neuropeptides POMC/CART and on feeding in C57BL/6 mice.

\section{MATERIALS AND METHODS}

\section{Plant material}

Roots of Scutellaria baicalensis Georgi were purchased from an herb market in Seoul. The plant was authenticated and deposited (\#SJ-0143) at the Jung San Herbarium, Hwaeseong-City, Republic of Korea.

\section{Purification of baicalin from the roots of $\boldsymbol{S}$. baicalensis}

The dried roots of $S$. baicalensis $(1.2 \mathrm{~kg})$ was finely powdered with a blender, extracted with $80 \%$ aqueous methanol $(6 \mathrm{~L})$ three times at $80^{\circ} \mathrm{C}$ for $4 \mathrm{~h}$, and filtered (Whatman No. 2, $30 \mathrm{~cm}$ in diameter). The combined filtrate was concentrated in vacuum at $45^{\circ} \mathrm{C}$ and gave a yield of about $65 \%$ (based on the weight of the dried material). The extract $(780 \mathrm{~g})$ was sequentially partitioned into $n$-hexane $(8 L \times 3)$, ethyl acetate $(8 L \times 3)$, and water-soluble $(8 L)$ portions for subsequent bioassay. The organic solvent- soluble fractions were concentrated to dryness by rotary evaporation at $40^{\circ} \mathrm{C}$, and the water-soluble fraction was concentrated at $50^{\circ} \mathrm{C}$.

Due to its potent activity, the water-soluble extracts (500 g) were subjected to open-column chromatography (Diaion HP-20, column size: $11 \times 120 \mathrm{~cm}$, resin wet volume 2 kg; Mitsubishi Chemical Co. Ltd., Tokyo, Japan) and eluted successively with a stepwise gradient of distilled water (DW)-methanol with increasing proportions of methanol. The respective fractions were evaporated to dryness.

The water-soluble fraction gave five subfractions (W1W5). Subfraction W4 (about $26 \mathrm{~g}$ ) isolated by removal of the solvent was chromatographed on a Lobar A column chromatography (low-pressure liquid chromatography: LPLC) and successively eluted with a stepwise gradient of water-methanol with increasing proportions of methanol. W4 gave eight subfractions (W41-W48). Subfraction W43 $(9.3 \mathrm{~g})$ was recrystallized in DW. Finally, the potent active principle 1 (W431, about $3.2 \mathrm{~g}$ ) was obtained on recrystallization using DW. W431 was obtained as light yellow needles and had the molecular formula $\mathrm{C}_{21} \mathrm{H}_{18} \mathrm{O}_{11}$ (Fig. 1) as determined by LC-EI-MS $(\mathrm{m} / \mathrm{z})$ and ${ }^{1} \mathrm{H}-\mathrm{NMR}$. The proton<smiles>O=C(O)C1CC(Oc2cc3oc(-c4ccccc4)cc(=O)c3c(O)c2O)C(O)C(O)C1O</smiles>

\section{Baicalin}

Fig. 1. Structure of baicalin.

signals and MS data of this compound were largely consistent with those reported by Sujuan et al. (2005).

Baicalin: Light yellow crystals, El-MS m/z: $447[\mathrm{M}]^{+}$, ${ }^{1} \mathrm{H}$-NMR (DMSO-d6) $\delta: 12.60(1 \mathrm{H}, \mathrm{s},-\mathrm{OH}), 8.65(1 \mathrm{H}, \mathrm{s}$, $-\mathrm{OH}), 8.07(2 \mathrm{H}, \mathrm{m}), 7.61(3 \mathrm{H}, \mathrm{m}), 7.04(1 \mathrm{H}, \mathrm{s}), 7.01(1 \mathrm{H}$, s).

\section{Animal experimental procedure}

Five-week-old male C57BL/6J mice (Daehan Biolink Co., Ltd., Seoul, Republic of Korea) were individually housed under a $12 \mathrm{~h} / 12 \mathrm{~h}$ dark/light cycle (lights on from 06:00 to $18: 00$ ) at $22^{\circ} \mathrm{C}$ under specific pathogen-free conditions. Mice were fed a normal diet (Cargill Agri Purina Inc., Seoul, Republic of Korea) and were 6 weeks old at the time of the experiments. Mice were deprived of food for $24 \mathrm{~h}$ (from 15:00 to 15:00) and then injected (every $24 \mathrm{~h}$ ) intraperitoneally with either baicalin $(10 \mathrm{mg} / \mathrm{kg}$ body weight) or vehicle alone (olive oil). After intraperitoneal injection, mice were returned immediately to their home cages and presented a preweighed amount of food. Food intake was measured serially $0-3,3-24$, and $24-48 \mathrm{~h}$ after injection. All of the animal protocols used in this study were approved by the Committee for Animal Experiments of Jung San Bio Technology.

\section{Immunocytochemistry}

Briefly, at $48 \mathrm{~h}$ after baicalin administration, the mice were perfused transcardially under deep $\mathrm{CO}_{2}$ anesthesia with physiological saline followed by formalin. After perfusion, their brains were removed, postfixed overnight with formalin at $4^{\circ} \mathrm{C}$, and submerged in $30 \%$ sucrose at $4^{\circ} \mathrm{C}$ overnight; then, sections were cut at a thickness of $20 \mu \mathrm{m}$ on a Leica Cryostat (Leica, Wetzlar, Germany). Sections were mounted on slide glasses and blocked with $5 \%$ fetal 

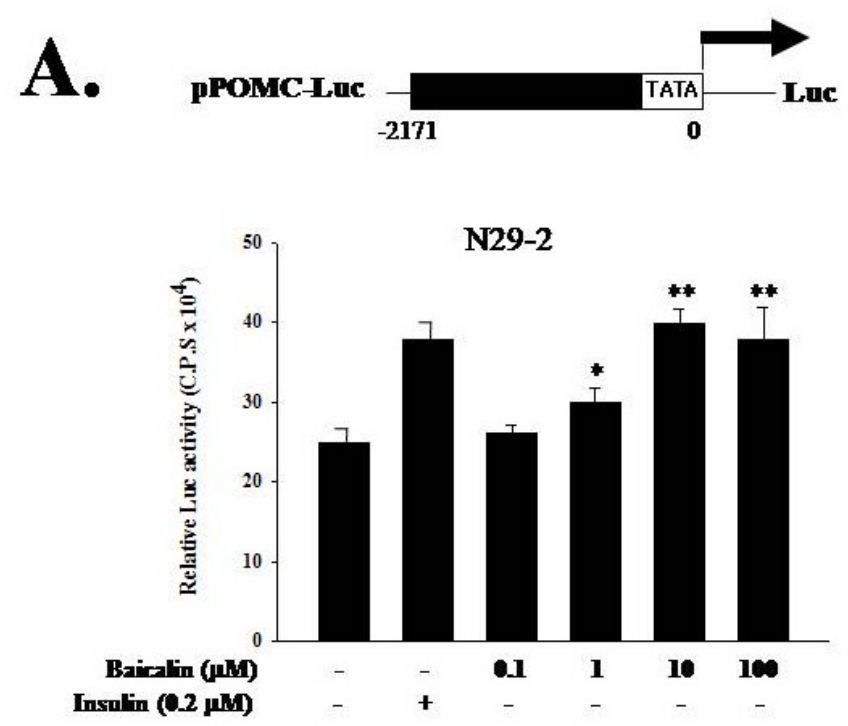

B.
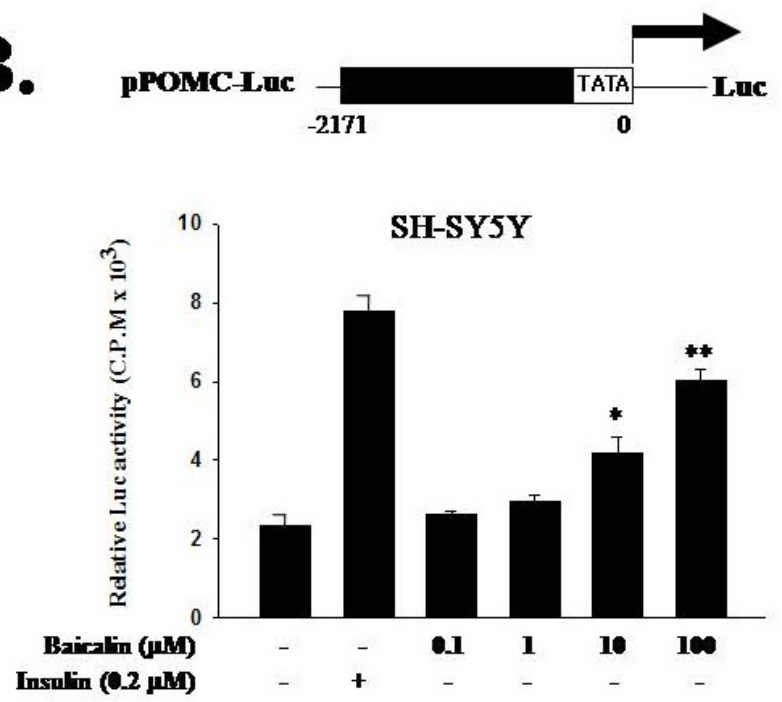

Fig. 2. Baicalin upregulated human $P O M C$ promoter [5'-flanking region of the human POMC $(-2,171 \mathrm{k} / \mathrm{b})]$-driven luciferase activity in a dose-dependent manner. Luciferase activity was upregulated by treatment with baicalin in N29-2 cells (A) and SH-SY5Y cells (B). ${ }^{*} p<0.05,{ }^{* *} p<0.01$.

bovine serum. Sections were then incubated with rabbit polyclonal anti-human POMC antibody (1:200; Santa Cruz Biotechnology, Inc., Santa Cruz, CA, USA) and goat polyclonal anti-human CART antibody (1:200; Santa Cruz Biotechnology, Inc.) overnight at room temperature. Sections were washed with PBS and incubated for $1 \mathrm{~h}$ with biotin-conjugated mouse anti-rabbit $(1: 1,000$; Santa Cruz Biotechnology, Inc.) and anti-goat secondary antibodies (1:1,000; Santa Cruz Biotechnology Inc.), and then treated with the avidin-biotin-peroxidase complex (ABC; Vector
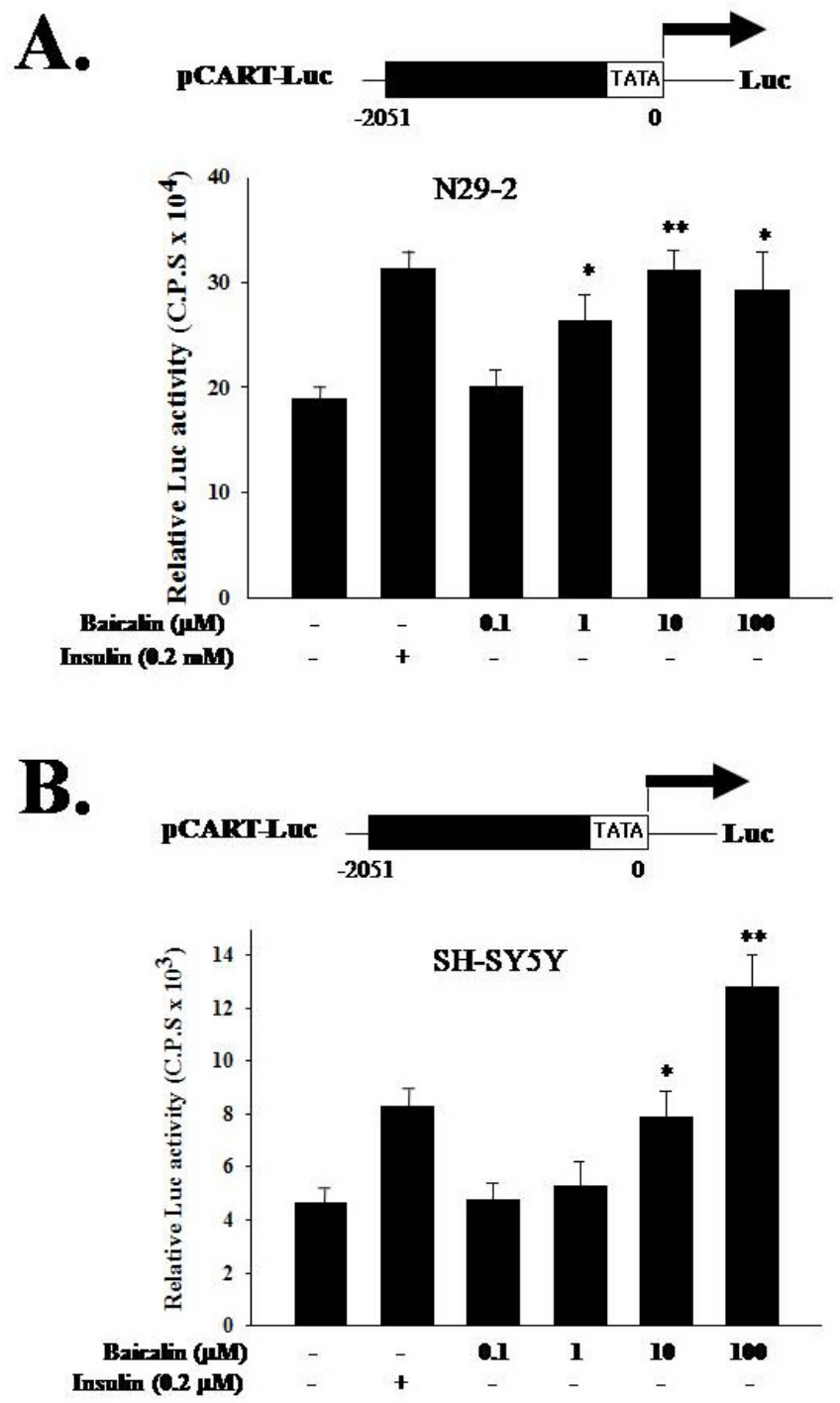

Fig. 3. Baicalin was also involved in the expression of CART in N29-2 cells (A) and SH-SY5Y cells (B). PCART-Luc vector containing the $5^{\prime}$-flanking region of the human CART promoter $(-2.0 \mathrm{k} / \mathrm{b})$ region. In N29-2 (A) and SH-SY5Y (B) cells, level of CART-promoter induced luciferase expression by baicalin treatment. ${ }^{*} p<0.05,{ }^{* *} p<0.01$.

Laboratories, Burlingame, CA, USA). The slides were then detected with diaminobenzidine and hydrogen peroxide to visualize the peroxidase reaction. After stopping the reaction, the sections were mounted in mounting medium for further analysis.

\section{Cell culture}

Mouse N29-2 hypothalamic cells were purchased from Cellutions Biosystems (Toronto, ON, Canada). Human hepatoblastoma HepG2 cells and human neuroblastoma SH-SY5Y cells were obtained from the American Type 
A.

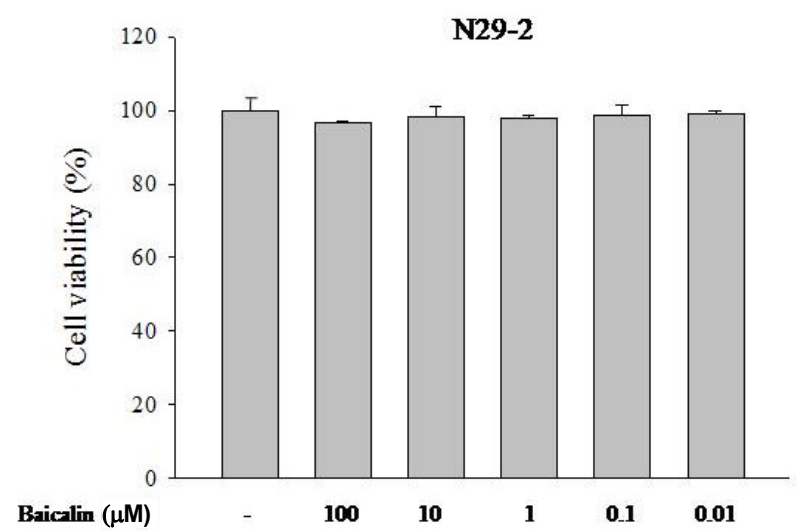

B.

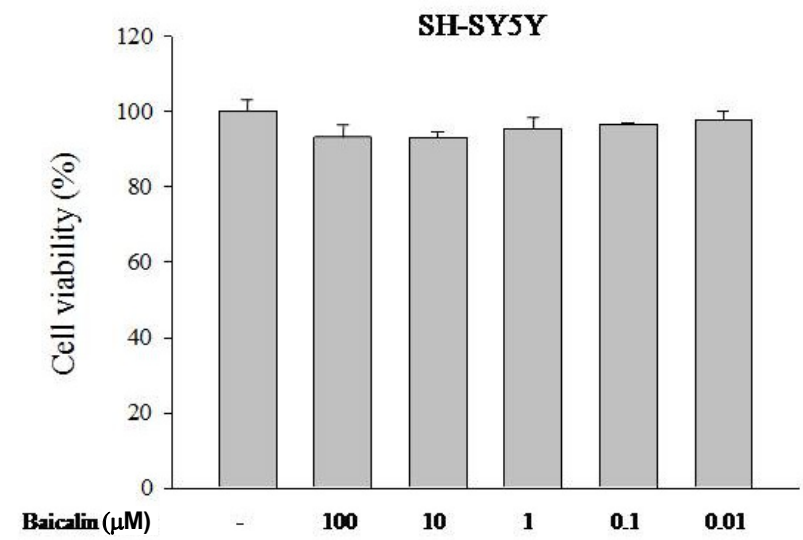

Fig. 4. MTT assay of baicalin. Baicalin does not have a cytotoxic effect in N29-2 or SH-SY5Y cells at concentrations of $0.01,0.1,1,10$, and $100 \mu \mathrm{M}$.

Culture Collection (ATCC No. CRL-2266). The cells were grown in Dulbecco's modified Eagle's medium (DMEM) containing $5 \%$ fetal bovine serum (Lonza, Bucheon-Si, Gyeonggi-Do Republic of Korea) in the presence of antibiotics at $37^{\circ} \mathrm{C}$ with $5 \% \mathrm{CO}_{2}$ in air.

\section{Construction of pPOMC-Luc and pCART-Luc vectors}

For cloning of the pGL4.15-basic luciferase reporter vector, five proximal regions of the POMC and CART genes were generated by PCR using Taq DNA polymerase from HepG2 genomic DNA. The following primers were used for pPOMC-Luc: [Forward: 5'-CGG GGT ACC CGC CTA CCC AGT GAT TC-3', Reverse: 5'-ACTG AAG CTT CTG TCT CGG GAG GCT GCT C-3'] and for pCART-Luc [Forward: 5'-CGG GGT ACC GCT TAG AAT
AGT TTA AAG ATC ACT GG-3', Reverse: 5'-ACT GGA GCT CGT TCT GAA ACT CGT CGT TG-3']. The amplified POMC DNA fragments were cloned into the Kpnl/HindllI sites of the pGL4.15-basic plasmid. The CART DNA fragment was cloned at the Kpnl/Sacl sites of the pGL4.15 vector.

\section{Cell culture and luciferase assay}

N-29-2 and SH-SY5Y cells were transfected using the FuGene6 Reagent (Roche Diagnostics, Mannheim, Germany) according to the manufacturer's protocol. Each 35 -mm cell culture dish received equimolar amounts $(2 \mu \mathrm{g})$ of reporter plasmids. After transfection for $8 \mathrm{~h}$, the medium was replaced with fresh medium for $12 \mathrm{~h}$. Cells were then selected by $2 \mu \mathrm{g} / \mathrm{ml}$ (final concentration) puromycin for 7 days, and $1 \times 10^{5}$ cells/well were seeded into 24 -well plates for $12 \mathrm{~h}$ and then changed to serum-free media for $24 \mathrm{~h}$. Baicalin (final concentration, 4.0-0.16 $\mu \mathrm{M}$ ) was added. Six $\mathrm{h}$ after treatment with baicalin, cells were washed twice with phosphate buffered saline (PBS), followed by addition of $250 \mu$ l of lysis buffer (125 mM Tris, pH 7.8, 2 mM DTT, 1 mM EDTA, $10 \%$ glycerol, $1 \%$ Triton X-100) and incubated at room temperature for $10 \mathrm{~min}$. The supernatant was collected after centrifugation of the crude lysate at $11,000 \times \mathrm{g}$ for $2 \mathrm{~min}$. Lysate $(50 \mu \mathrm{l})$ was used for the luciferase assay using a VICTOR ${ }^{\mathrm{TM}}$ light (PerkinElmer, Shelton, CT) according to the manufacturer's instructions. The amount of protein was calculated by Bradford assay, and insulin was included as a positive control. All experiments were repeated at least three times.

\section{MTT assay for evaluating cell viability}

MTT assay was performed $24 \mathrm{~h}$ after baicalin treatment. MTT solution $(5 \mathrm{mg} / \mathrm{ml})$ was prepared in PBS and filtered through a $0.2-\mu \mathrm{m}$ filter. Then, the medium of each well was replaced with $50 \mu \mathrm{l}$ of MTT plus $500 \mu \mathrm{l}$ of DMEM without phenol red. Cells were incubated for an additional $4 \mathrm{~h}$ at $37^{\circ} \mathrm{C}$ with $5 \% \mathrm{CO}_{2}, 95 \%$ air, $100 \%$ humidity. After $4 \mathrm{~h}$, the MTT solution was removed and replaced with $250 \mu$ of DMSO. The plates were further incubated for $5 \mathrm{~min}$ at room temperature, and the optical density (OD) of the wells was determined at a wavelength of $595 \mathrm{~nm}$.

\section{Statistic analysis}

Data are expressed as means \pm SE or SD. Differences between the values were considered significant at $p<$ 0.05 . Body weight changes were analyzed by Student's t-test. 


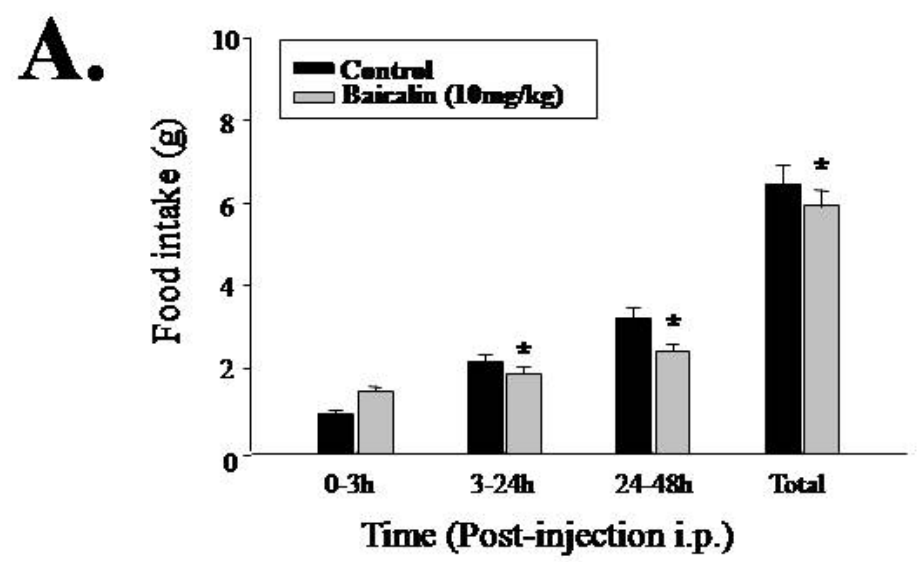

B.

POMC
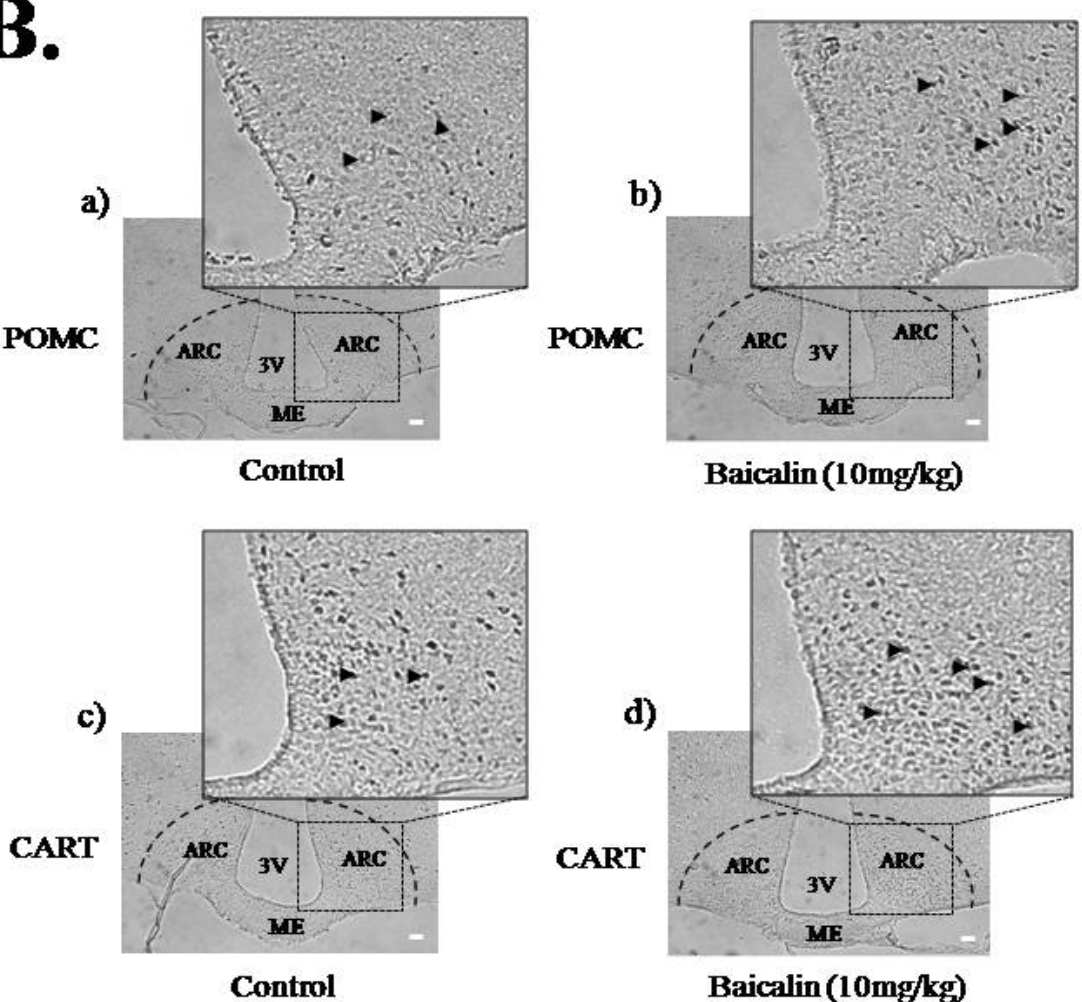

Fig. 5. Food intake of mice 3,24 , and $48 \mathrm{~h}$ after intraperitoneal (i.p.) injection of baicalin (10 $\mathrm{mg} / \mathrm{kg} \mathrm{bw}$ ) and the expression of POMC and CART in the arcuate nucleus of the hypothalamus. (A) Note that the scale for the 0- to 3-h food intake values is expanded relative to the scale for the 3- to 24-h and 24- to 48-h values. Mice were fasted for $24 \mathrm{~h}$ before i.p. injection of baicalin (10 mg/kg). (B) Immunohistochemical analysis of POMC and CART in the arcuate nucleus of controls $(a, c)$ and baicalin-treated $(b, d)$ mice. Baicalin $(10 \mathrm{mg} / \mathrm{kg})$ considerably increased POMC and CART expression in the arcuate nucleus. All data are means \pm SEM of 6 mice per group. ARC: arcuate nucleus, $3 \mathrm{~V}$ : third ventricle, ME: median eminence, Scale bar: $100 \mu \mathrm{m}$, Arrows mean the POMC or CART positive cells. ${ }^{*} p$ $<0.05$ vs. CON group.

\section{RESULTS}

To search for active compounds that regulate the anorexigenic neuropeptides POMC and CART, we designed permanent cell assay systems using human POMC or CART promoter-driven luciferase (pPOMC-Luc and pCARTLuc, respectively) permanently transformed into N29-2 and SH-SY5Y cells (Fig. 2 and 3). Using these cell lines, about 2300 plant extracts were screened for their expression-promoting activity (data not shown), and the roots of Scutellaria baicalensis was selected for this study. Baicalin is a flavonoid isolated from the roots of Scutellaria baicalensis Georgi. To investigate whether baicalin leads to stimulation of POMC and CART promoter activity, we tested human POMC (pPOMC-Luc) or CART (pCARTLuc) promoter-driven luciferase activity in both N29-2 and SH-SY5Y cells (Fig. 2 and 3 ). The $50 \%$ effective concentration $\left(\mathrm{EC}_{50}\right)$ of baicalin was $8.0 \mu \mathrm{M}$ for POMC and $1.8 \mu \mathrm{M}$ for CART in the N29-2 cells. Baicalin at $10 \mu \mathrm{M}$ increased POMC promoter-driven luciferase activity by $164 \%$, whereas it upregulated CART promoter-dependent luciferase activity by $168.4 \%$. These luciferase activities were confirmed in SH-SY5Y cells to exclude the possibility that the promoter is nonfunctional in human cells. Treatment with baicalin $(100 \mu \mathrm{M})$ induced significant increases in POMC and CART promoter-driven luciferase activities in 
SH-SY5Y cells compared with controls. Baicalin did not have significant cell cytotoxicity in either cell line (Fig. 4). To confirm the effectiveness of baicalin against food intake, mice were deprived of food for $24 \mathrm{~h}$ before injection of baicalin $(10 \mathrm{mg} / \mathrm{kg})$ (Fig. 5A). No effects on food intake were observed at $3 \mathrm{~h}$ after intraperitoneal (i.p.) injection of either baicalin or vehicle control. Baicalin-treated mice showed significant reductions in food intake at $24 \mathrm{~h}(13 \%$, $p<0.05)$ and $48 \mathrm{~h}(24 \%, p<0.05)$ after i.p. injection compared with vehicle-treated controls.

To detect the upregulation of POMC and CART in the arcuate nucleus of the hypothalamus in the baicalin-administered mice, brain immunohistochemistry was examined to determine POMC and CART expression on brain sections (Fig. 5B). POMC and CART were detected in the arcuate nucleus of the hypothalamus in control mice. However, these molecules were considerably upregulated in the baicalin $(10 \mathrm{mg} / \mathrm{kg})$-treated mice.

\section{DISCUSSION}

Baicalin is known to have many biological functions, including antimicrobial activities (Gao et al., 1999), antitumor effects (Chan et al., 2000; Wang et al., 2008; Li-Weber, 2009), anti-inflammatory (Lin et al., 2008), and antiviral activities (Li et al., 2000; Wang et al., 2004). However, the functional correlation between appetite inhibition and baicalin is currently unknown. pPOMC-Luc and PCART-Luc were expressed at considerable levels in both mouse N29-2 and human SH-SY5Y cells, but the baicalin treatment stimulated their expression levels significantly more than control levels in a dose-dependent manner (Fig. 2 and 3). Considering these effects of baicalin on anorexigenic neuropeptides, it was postulated that baicalin should affect the POMC/CART levels in the arcuate nucleus of the hypothalamus. In the CNS, POMC and CART are colocalized in the arcuate nucleus of the hypothalamus (Broberger, 1998; Elias, 1998; Koylu et al., 1998). The results of the present study indicated that neuronal cells treated with baicalin $(10 \mathrm{mg} / \mathrm{kg})$ showed elevated expression of POMC and CART in the arcuate nucleus of the hypothalamus (Fig. 5B). These results should be correlated with the short-term $(48 \mathrm{~h})$ reduced food intake in C57BL/6 mice, and they suggest that baicalin plays an important role in the upregulation of POMC and CART.

In summary, we demonstrated that baicalin decreased short-term food intake with the upregulation of POMC and CART in the arcuate nucleus of the hypothalamus. The patterns of anorexigenic neuropeptide gene expression were essentially similar in POMC and CART promoter- driven mouse and human neuronal cells. These observations suggested that the upregulation of $\mathrm{POMC/}$ CART in neuronal cells indicates a positive correlation with increased anorexigenic neuropeptide levels in the arcuate nucleus of the hypothalamus by baicalin. Although our results indicated that the effects of baicalin may not be particularly strong, it is considered a good supplement to reduce short-term food intake without cytotoxic effects. Further studies using models of prolonged food intake in a specific area of the hypothalamus may help us to understand the long-term effects of baicalin.

\section{ACKNOWLEDGMENTS}

This work was supported by Gyeonggi Research Institute (GRI) grant A08081910.

\section{REFERENCES}

Broberger, C., De Lecea, L., Sutcliffe, J. G. and Hokfelt, T. (1998). Hypocretin/ orexin- and melanin-concentrating hormone-expressing cells form distinct populations in the rodent lateral hypothalamus: relationship to the neuropeptide $\mathrm{Y}$ and agouti gene-related protein systems. J. Comp. Neurol. 402, 460-474.

Catania, A. (2008). Neuroprotective actions of melanocortins: a therapeutic opportunity. Trends Neurosci. 31, 353-360.

Chai, B., Li, J. Y., Zhang, W., Ammori, J. B. and Mulholland, M. W. (2007). Melanocortin-3 receptor activates MAP kinase via PI3 kinase. Regul. Pept. 139, 115-121.

Chan, F. L., Choi, Z. Y. and Huang, Y. (2000). Induction of apoptosis in prostate cancer cell lines by a flavonoid, baicalin. Cancer Lett. 160, 218-219.

Coll, A. P. and Loraine-Tung, Y. C. (2009). Pro-opiomelanocortin (POMC)-derived peptides and the regulation of energy homeostasis. Mol. Cell Endocrinol. 300, 147-151.

Cone, R. D. (2000). The melanocortin-4 receptor. In The Melanocortin Receptors (R. D. Cone, Ed), pp. 405-447. Humana Press, New Jersey.

Eberle, A. N. (2000). Proopiomelanocortin and the melanocortin peptides. In The Melanocortin Receptors (R. D. Cone, Ed), pp. 3-67. Humana Press, New Jersey.

Elias, C. F., Saper, C. B., Maratos-Flier, E., Tritos, N. A., Lee, C. and Kelly, J. (1998). Chemically defined projections linking the medio basal hypothalamus and the lateral hypothalamic area. J. Comp. Neurol. 402, 442-459.

Emmerson, P. J., Fisher, M. J., Yan, L. Z. and Mayer, J. P. (2007). Melanocortin-4 receptor agonists for the treatment of obesity. Curr. Top. Med. Chem. 7, 1121-1130.

Fan, W., Boston, B. A., Kesterson, R. A., Hruby, V. J. and Cone, R. D. (1997). Role of melanocortinergic neurons in feeding and the agouti obesity syndrome. Nature 385, 165-168.

Fu, L. Y. and van den Pol, A. N. (2008). Agouti-related peptide and $\mathrm{MC} 3 / 4$ receptor agonists both inhibit excitatory hypothalamic ventromedial nucleus neurons. J. Neurosci. 28, 
5433-5449.

Gantz, I. and Fong, T. M. (2003). The melanocortin system. Am. J. Physiol. Endocrinol. Metab. 284, 468-474.

Gao, Z., Huang, K., Yang, X. and Xu, H. (1999). Free radical scavenging and antioxidant activities of flavonoids extracted from the radix of Scutellaria baicalensis Georgi. Biochim. Biophys. Acta. 1472, 643-650.

Higuchi, H., Yamaguchi, T. and Niki, T. (2006). Regulation of hypothalamic neuropeptide expression and feeding behavior in NPY-Y5 knockout (KO) mice. Nippon Yakurigaku Zasshi 127, 92-96.

Huang, H., Yang, A., Li, D., Fu, L., Yu, N. and Su, W. (2009). Baicalin suppresses expression of Chlamydia protease-like activity factor in Hep-2 cells infected by Chlamydia trachomatis. Fitoterapia 80, 448-452.

Irani, B. G. and Haskell-Luevano, C. (2005). Feeding effects of melanocortin ligands a historical perspective. Peptides 26, 1788-1799.

Kalra, S. P. and Kalra, P. S. (2003). Neuropeptide Y: a physiological orexigen modulated by the feedback action of ghrelin and leptin. Endocrine 22, 49-56.

Koylu, E. O., Couecyro, P. R., Lambert, P. D. and Kuhar, M. J. (1998). Cocaine- and amphetamine-regulated transcript immunohistochemical localization in the rat brain. J. Comp. Neurol. 391, 115-132.

Li, B. Q., Fu, T., Dongyan, Y., Mikovits, J. A., Ruscetti, F. W. and Wang, J. M. (2000). Flavonoid baicalin inhibits HIV-1 infection at the level of viralentry. Biochem. Biophys. Res. Commun. 276, 534-538.

Li-Weber, M. (2009). New therapeutic aspects of flavones: the anticancer properties of Scutellaria and its main active constituents Wogonin, Baicalein and Baicalin. Cancer Treat. Rev. 35, 57-68.

Lin, L. L., Li, K. G., Hui, W., Ying, X., Xiong, F. W., Zhang, Y. H.,
Xue, X., Qi, X. M. and Ren, J. (2008). Baicalin inhibits macrophage activation by lipopolysaccharide and protects mice from endotoxin shock. Biochem. Pharmacol. 75, 914922.

Morton, G. J., Cummings, D. E., Baskin, D. G., Barsh, G. S. and Schwartz, M. W. (2006). Central nervous system control of food intake and body weight. Nature 443, 289-295.

Murphy, K. G. and Bloom, S. R. (2006). Gut hormones and the regulation of energy homeostasis. Nature 444, 854-859.

Ollmann, M. M., Wilson, B. D., Yang, Y. K., Kerns, J. A., Chen, Y., Gantz, I. and Barsh, G. S. (1997). Antagonism of central melanocortin receptors in vitro and in vivo by agouti-related protein. Science 278, 135-138.

O'Rahilly, S. and Yeo, G. S. (2004). Farooqi IS. Melanocortin receptors weigh in. Nat. Med. 10, 351-352.

Schwartz, M. W., Woods, S. C., Porte, D. Jr., Seeley, R. J. and Baskin, D. G. (2000). Central nervous system control of food intake. Nature 404, 661-671.

Sujuan, W., Ailing, S. and Renmin, L. (2005). Separation and purification of baicalin and wogonoside from the Chinese medicinal plant Scutellaria baicalensis Georgi by high-speed counter-current chromatography. J. Chromatogr. A. 1066 243-247.

Vicentic, A. and Jones, D. C. (2007). The CART (cocaine- and amphetamine-regulated transcript) system in appetite and drug addiction. J. Pharmacol. Exp. Ther. 320, 499-506.

Wang, N., Tang, L. J., Zhu, G. Q., Peng, D. Y., Wang, L., Sun, F. N. and Li, Q. L. (2008). Apoptosis induced by baicalin involving up-regulation of P53 and bax in MCF-7 cells. J. Asian Nat. Prod. Res. 10, 1129-1135.

Wang, Q., Wang, Y. T., Pu, S. P. and Zheng, Y. T. (2004). Zinc coupling potentiates anti-HIV-1 activity of baicalin. Biochem. Biophys. Res. Commun. 324, 605-610. 